\title{
Studies on plasma amino acids in East African adults in relation to endomyocardial fibrosis
}

\author{
By M. A. CRAWFORD AND M. M. GALE \\ Nuffield Institute of Comparative Medicine, The Zoological Society \\ of London, Regent's Park, London, NW I \\ AND K. SOMERS AND I. L. HANSEN \\ Departments of Medicine and Biochemistry, Makerere University \\ College, Kampala, Uganda
}

(Received I May 1969--Accepted 21 November 1969)

\begin{abstract}
I. An examination has been made of the plasma amino acids of adult Uganda Africans at risk to endomyocardial fibrosis compared with people from areas where the disorder is rare. The amino acid profile, both free and in the protein of the main staples, has also been examined.

2. Plasma tryptophan was found to be low in adults at risk and intermediate in Africans receiving a higher protein intake, as compared with Europeans whose protein intake might include more than $40 \%$ as animal products.

3. Leucine and valine were also low in the plasma of adult Africans at risk.

4. The non-essential amino acids alanine and glycine were increased in the adult Africans at risk.

5. The similarity of these changes with the changes seen in kwashiorkor by other workers suggests that adherence to limited vegetable diets may introduce a chronic stress with regard to certain essential amino acids.

6. Studies on the vegetable staples used by Africans established that they are particularly poor in tryptophan and such Africans are probably dependent on other sources for their tryptophan. None of the staples was a rich source of leucine. Plantain contained relatively large amounts of histidine, and cassava of arginine.

7. A comparative study of muscle protein suggests that the composition is similar regardless of diet and species. Leucine is quantitatively one of the most important amino acids in the muscle profile.

8. The above findings are discussed in the context of the requirements for heart muscle and the high incidence of cardiomyopathies within such African communities.
\end{abstract}

We have been interested in the question of nutrition and endomyocardial fibrosis. During a study on the dietary and plasma serotonin $(5$-hydroxytryptamine- $5 \mathrm{HT})$ and urinary indoles it became apparent that Africans living on high-bulk diets excreted relatively large amounts of indolylacrylic acid and its conjugates (Banwell \& Crawford, I963; Crawford, 1964). We confirmed the bacterial origin of this compound and partly described its metabolism (Hansen \& Crawford, 1966 and unpublished; Crawford, I $968 \mathrm{a}$ ). The similarity of the African urinary indole pattern to that in Hartnup disease suggested a form of amino acid malabsorption (Milne, Crawford, Girao \& Loughridge, 1960 $a, b$; Crawford, I968a). Bacterial degradation of an essential amino acid such as tryptophan could be important to the nutrition of people on a protein-low diet. On the other hand, a contribution to the host's nutrition by auto-digestion of gut bacteria cannot be entirely excluded (Gustafsson, I $968 a, b$ ). It therefore seemed important to analyse plasma tryptophan. Although bacterial action on essential amino acids might be a factor relevant to supply, the importance of the low content of essential amino acids in the actual foods might be even more important for tissue construction and repair. 
The highest incidence of endomyocardial fibrosis is alleged to be in the lower socioeconomic groups (Somers \& D'Arbela, 1964; Shaper \& Coles, 1965 ; Somers, Brenton \& Sood, I 968 ; Tulloch, Kanyerezi \& Sood, I968). Our own inquiries and those of Bennett, Jelliffe, Jelliffe \& Moffat ( 1968 ) indicate that the main difference between the diets of the lower and higher socio-economic groups is a reliance on available staples and lack of animal protein in the former group. These staples are low in protein and fat and rich in carbohydrates. Whitehead (1964, 1965) has shown that an imbalance in essential and non-essential amino acids is apparent in Uganda children suffering from kwashiorkor. We therefore felt it worth examining the balance of plasma amino acids in adults in the lower socio-economic group eating high-bulk, low-protein foods.

Because the common degenerative cardiac diseases in the tropics involve heart muscle, we carried out a comparative study on the amino acid composition of muscle from different mammals adapted to different diets. We hoped to establish whether any general principle operated relating diet and muscle composition, as muscle is both the largest protein constituent of the body and also accounts for a large proportion of heart tissue.

\section{METHODS}

\section{Subjects}

Volunteers for plasma amino acid studies were obtained from healthy subjects of communities in which endomyocardial fibrosis was known to occur; cultivators from Musaka and Mengo districts were selected from a rural environment in which the main dietary staples were plantain (matoke), sweet potato and cassava (plantain-root crop community), with little animal or fish protein (Dean \& Burgess, 1962; Uganda Atlas, 1962). The tribal origin of these people was Ganda and Rwanda; they were all young adults ( $17-35$ years). For comparison, a group of healthy Africans of Luo origin living on the Kenya border in Bukedi district were studied. These people were predominantly grain eaters but included significant amounts of both fish and milk in their diets (Dean \& Burgess, 1962). A third group consisted of healthy Europeans who derived more than $40 \%$ of their protein from animal and fish products (Greaves \& Tan, I966; Crawford, 1968b). Blood samples were obtained by venepuncture between 10.00 and $12.00 \mathrm{~h}$, before the midday meal, to avoid diurnal variations.

\section{Amino acids in plasma}

Amino acids were determined in food in a Technicon amino acid analyser with a nor-leucine internal and external standard. Plasma tryptophan was assayed by the norharman method described by Denckla \& Dewey (1967). This method was found to be reproducible when protein solutions were used, but tryptophan by itself did not give adequate reproducibility. Addition of the plasma to tryptophan appeared to stabilize the molecule during the heat formation of the harman product. It is probable that absorption on to the protein surface accounts for the stabilization by plasma, and therefore standardization was carried out both with a norharman standard and with a freshly prepared tryptophan standard added to plasma. This stabilization has been noted before with other indoles (Weissbach, King, Sjoerdsma \& Udenfriend, 1959). 


\section{Free amino acid content of foodstuff}

Extraction of the free amino acids from the staple foodstuffs studied was carried out after freezing and thawing. Acetone-water ( $9: \mathrm{I})$ was used to extract the free amino acids. This method gave the highest quantitative yields. The amino acids were determined by the method used for plasma.

\section{Amino acids in food proteins}

Foodstuffs were obtained from Kampala, Uganda, by air and the results represent the mean of three analyses on three different batches. Analysis, by the same method as used for plasma, for the amino acid profile of foodstuffs was carried out after acid hydrolysis. The conditions of hydrolysis are $110^{\circ}$ in $6 \mathrm{~N}-\mathrm{HCl}$ ( $\mathrm{rg}$ material to $100 \mathrm{ml}$ ) under nitrogen for $28 \mathrm{~h}$. After the first $2 \mathrm{~h}$ of hydrolysis the supernatant fraction was separated by centrifugation, a further $5 \circ \mathrm{ml} / \mathrm{g}$ of $6 \mathrm{~N}-\mathrm{HCl}$ were added to the precipitate and hydrolysis was continued separately; the supernatant fractions were finally recombined. This technique was found to be suitable for high-carbohydrate foodstuffs but cystine recoveries were low $(78 \%)$ in our system and peak formation was poor. This procedure destroys the tryptophan, and consequently other methods were explored.

Difficulties involved in the estimation of tryptophan are many and varied. A period of $7 \mathrm{~d}$ is required for microbiological determination of tryptophan with the aid of the organism Lactobacillus arabinosus 17-5. Chromatographic separation of tryptophan and its metabolites followed by chemical estimation or by nephelometry is unsatisfactory since these compounds are degraded during chromatographic procedures, by elevated temperatures, ultraviolet light and low $\mathrm{pH}$. In this laboratory food tryptophan was estimated by a method based on that published by Lombard \& de Lange (1965); the success of this method depends on: (I) enzymic hydrolysis of the protein with papain; (2) the addition of gelatin to all samples to provide an excess amino acid complex.

\section{RESULTS}

\section{Amino acid composition of plasma}

The plasma amino acid profile found in European communities was different from that of the African plantain-root crop communities (see Fig. I). Significant differences were found (Table I) between leucine, valine and isoleucine, which were proportionately lower in the plantain community; threonine was higher. Other differences were observed but the visual comparison of the profiles indicates both the different balance and scatter of the individual amino acids (Fig. r). Because of the nature of the analytical system, amino acids at low concentrations can be measured with less precision than at high concentration. Whilst we are not reporting significant differences for methionine, it is possible that more detailed study of a larger number of subjects may show differences. No significant difference was noticed in total plasma proteins in any of the groups studied here. 

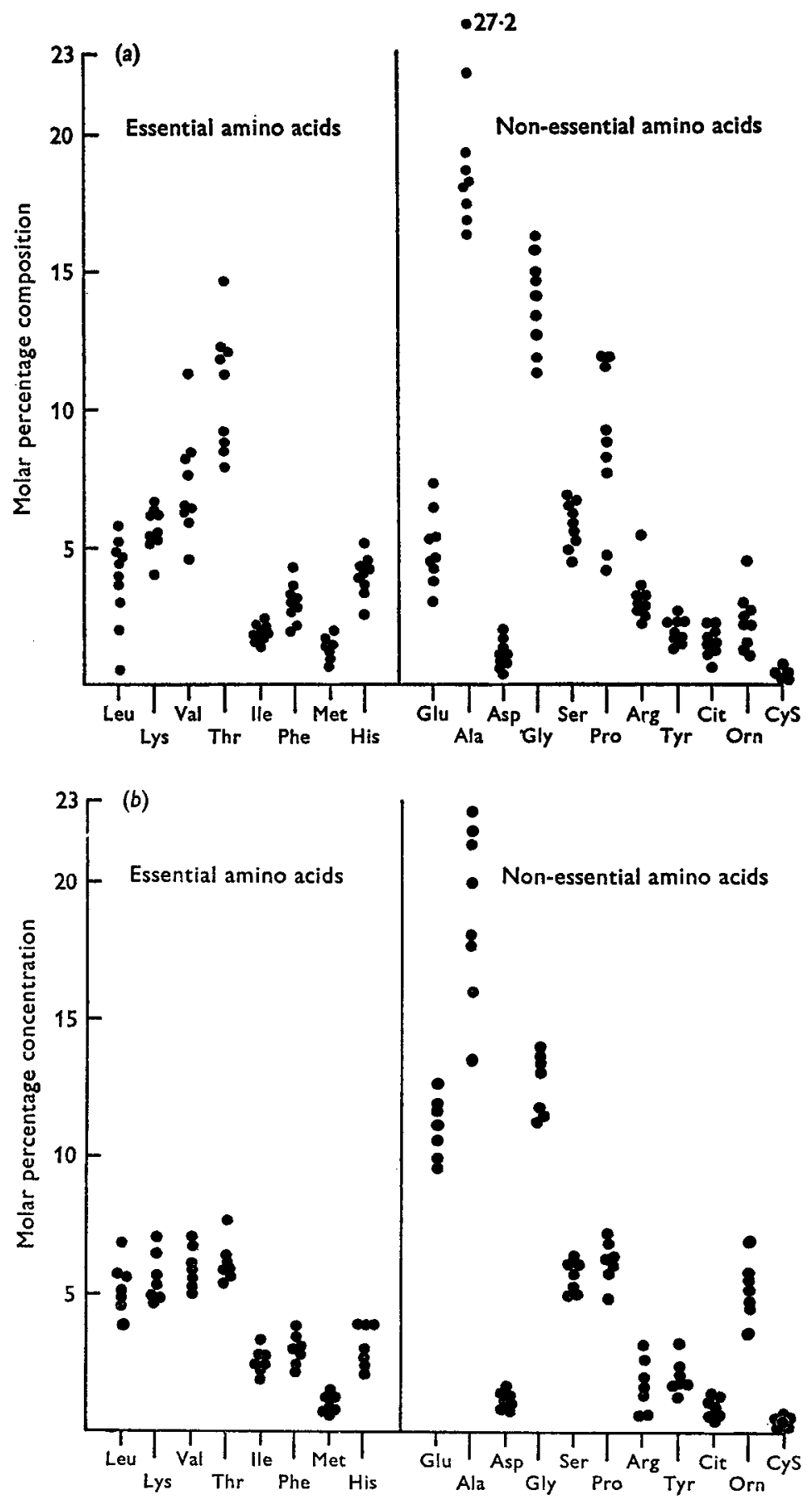

Fig. I $a$ and $b$. For legend see facing page. 


\section{Plasma tryptophan concentrations}

An assay of plasma tryptophan was carried out in (I) a plantain-root crop community, (2) an African community using a high proportion of fish and maize in their diet, and (3) a European community. From Table 2 it can be seen that the plantaineating community, as compared with the European group and other African communities, had significantly lower plasma tryptophan levels.

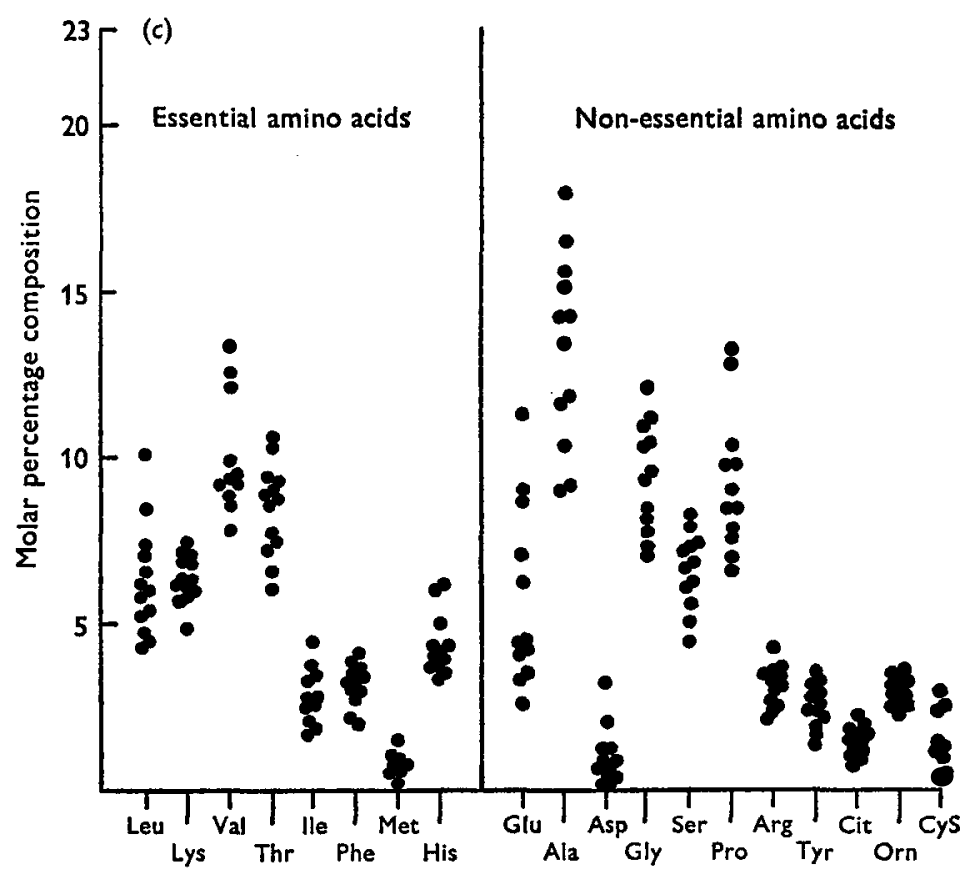

Fig. I. Plasma amino acid patterns of East African communities of different dietary habits. $a$, the plantain-root crop community, considered to be at risk to endomyocardial fibrosis; $b$, the grain-fish-milk community; $c$, European community. The amino acids are plotted in order of their quantitative importance to muscle protein (Fig. 2).

\section{Amino acid composition of dominant staple foodstuffs}

The values presented in Table 3 are from a limited number of samples (three in each instance) and more extensive observations are really required. However, these values do illustrate the trends that are likely to be present in large samples of the different foods. Although it is interesting to note the different balance of amino acids in the proteins, digestive efficiencies may also affect true availability. Cystine is not reported because of poor recovery, and tryptophan degenerates on the column. The analysis of the main staple foodstuffs demonstrated that the amino acid profile of the plantain was weighted with high concentrations of histidine; this imbalance was found both in the free and protein-bound amino acids (Tables 2 and 4 ). The amino acid profile of cassava protein was weighted with a high arginine concentration, but the sweet potato profile conformed reasonably well with the normal profile found for animal protein 
except for the negligible tryptophan content (Table 5) and low proportions of leucine and lysine; the above profiles agree reasonably with the results from single samples of West African products reported by Busson (1965).

Table I. Comparison of the proportions of plasma amino acids in Europeans and plantain eaters

\begin{tabular}{|c|c|c|c|c|c|}
\hline \multirow[b]{3}{*}{ Amino acid } & \multicolumn{4}{|c|}{ Plasma content (molar \%) } & \multirow{3}{*}{$\begin{array}{c}\text { Probability } \\
\text { of difference } \\
\text { by chance }\end{array}$} \\
\hline & \multicolumn{2}{|c|}{$\begin{array}{l}\text { Plaintain-root crop } \\
\text { community }(n=12)\end{array}$} & \multicolumn{2}{|c|}{$\begin{array}{c}\text { European } \\
\text { community }(n=14)\end{array}$} & \\
\hline & Mean & $\mathbf{S E}$ & Mean & SE & \\
\hline Leucine & 37 & $I \cdot 9$ & $5 \cdot 9$ & $2 \cdot 6$ & $\begin{array}{l}<0.010 \\
>0.005\end{array}$ \\
\hline Lysine & $5 \cdot 9$ & 0.5 & $6 \cdot 1$ & 0.5 & $>0.1$ \\
\hline Valine & 6.9 & $I \cdot 0$ & $9 \cdot 3$ & $2 \cdot 1$ & $\begin{array}{l}<0.005 \\
>0.001\end{array}$ \\
\hline Threonine & 10.7 & $4^{*} 9$ & $8 \cdot 5$ & $2 \cdot 6$ & $\begin{array}{l}<0.050 \\
>0.025\end{array}$ \\
\hline Isoleucine & $1 \cdot 8$ & 0.1 & $2 \cdot 5$ & 0.3 & $\begin{array}{l}<0.005 \\
>0.001\end{array}$ \\
\hline Phenylalanine & $2 \cdot 8$ & 0.5 & $2 \cdot 9$ & 0.5 & $>0.1$ \\
\hline Methionine & $I \cdot 2$ & 0.1 & $I \cdot I$ & $0 \cdot 1$ & $>0.1$ \\
\hline Histidine & $4 \cdot 9$ & $4 \cdot 6$ & 4.7 & 0.7 & $\begin{array}{l}>0.1 \\
>0.1\end{array}$ \\
\hline Glutamic & $5 \cdot 3$ & $4 \cdot 5$ & 3.9 & 0.5 & $>0.1$ \\
\hline Alanine & $19 \cdot 0$ & $\mathrm{II} 4$ & 147 & $2 \cdot 4$ & $\begin{array}{l}<0.005 \\
>0.001\end{array}$ \\
\hline Glycine & $13 \cdot 4$ & $I \cdot 9$ & $9 \cdot 7$ & 2.4 & $<0.001$ \\
\hline Serine & $5 \cdot 9$ & 0.7 & $6 \cdot 1$ & $I \cdot 0$ & $>0.1$ \\
\hline Proline & $8 \cdot 4$ & $8 \cdot 9$ & 10.9 & $4 \cdot 6$ & $>0.1$ \\
\hline Arginine & $2 \cdot 9$ & 0.3 & 3.0 & 0.3 & $>0.1$ \\
\hline Tyrosine & $\mathrm{I} \cdot 8$ & 0.2 & $2 \cdot 6$ & 0.3 & $\begin{array}{l}<0.010 \\
>0.005\end{array}$ \\
\hline Citrulline & $2 \cdot 0$ & 0.5 & $3 \cdot 1$ & 0.3 & $\begin{array}{l}<0.010 \\
>0.005\end{array}$ \\
\hline Ornithine & $2 \cdot 0$ & 0.5 & $2 \cdot 9$ & $0 \cdot 1$ & $\begin{array}{l}<0.010 \\
>0.005\end{array}$ \\
\hline Aspartic & $I \cdot I$ & 0.2 & 0.6 & 0.1 & $\begin{array}{l}<0.025 \\
>0.010\end{array}$ \\
\hline
\end{tabular}

Table 2. Plasma tryptophan content ( $\mu \mathrm{g} / \mathrm{ml})$ in East African communities of different dietary habits

$\begin{array}{lcccc} & \begin{array}{c}\text { European } \\ \text { community }\end{array} & A & B & \begin{array}{c}\text { Prain-fish-milk } \\ \text { crop }\end{array} \\ \text { No. } & 15 & 16 & 17 & 21 \\ \text { Mean } & 12 & 10 & 9 \cdot 9 & 8 \cdot 0 \\ \text { SE of the mean } & 0.7 & 1 \cdot 0 & 1 \cdot 1 & 0.7\end{array}$

The meat-eating Europeans, grain-fish-milk group B and the plantain-root crop group were from the same samples as described in Fig. I and Table $I$; the grain-fish-milk group A was from a different community who were alleged to eat more fish but whose plasma tryptophan content did not differ significantly from that of group B.

Values for the European community and plantain-root crop groups were significantly different $(P<0.001)$. 
The tryptophan content of the proteins from the three African staples was below the limits of detection of the method employed. This was not because the method was insufficiently sensitive to detect tryptophan in other low-protein foodstuffs (Table 5). Because of the inability to detect tryptophan in these staples, materials of a homogeneous nature whose approximate amino acid pattern was known were tested and compared with materials reported to have a moderately high tryptophan content. Finally, a selection of low-protein special diets were analysed for tryptophan; it was possible to establish the tryptophan content of most of them (Table 5).

Table 3. Molar percentage proportions of protein hydrolysates from skeletal muscle and from different staple foodstuffs in East Africa

\begin{tabular}{|c|c|c|c|c|c|c|}
\hline $\begin{array}{l}\text { Amino } \\
\text { acid }\end{array}$ & $\begin{array}{l}\text { Skeletal } \\
\text { muscle }\end{array}$ & Plantain & $\begin{array}{l}\text { Sweet } \\
\text { potato }\end{array}$ & Cassava & $\begin{array}{l}\text { Ground- } \\
\text { nuts }\end{array}$ & Maize \\
\hline \multicolumn{7}{|l|}{ Essential: } \\
\hline Leucine & 9.0 & $5 \cdot 9$ & $5 \cdot 8$ & $6 \cdot I$ & $7 \cdot 3$ & 14.0 \\
\hline Lysine & $7 \cdot 8$ & $4 \cdot I$ & 4.9 & $5^{\circ} 9$ & $3 \cdot 6$ & $3 \cdot 0$ \\
\hline Valine & $6 \cdot 3$ & $5 \cdot 4$ & $6 \cdot 4$ & 4.9 & $5 \cdot 2$ & $5 \cdot 6$ \\
\hline Threonine & 5.8 & 4.4 & $5 \cdot 1$ & 3.9 & 4.0 & 45 \\
\hline Isoleucine & $5 \cdot 6$ & $3 \cdot 6$ & 4.5 & $3 \cdot 1$ & 4.0 & $4 \% 4$ \\
\hline Phenylalanine & $4 \cdot 2$ & 4.2 & $4 \cdot 9$ & $4^{\cdot I}$ & $5 \cdot 2$ & $4^{\cdot 6}$ \\
\hline Methionine & $3 \cdot 5$ & $I \cdot 5$ & $I \cdot I$ & $I \cdot O$ & $2 \cdot 3$ & $2 \cdot 0$ \\
\hline Histidine & $2 \cdot 8$ & $8 \cdot 5$ & $I \cdot 2$ & $2 \cdot 0$ & $2 \cdot 5$ & $2 \cdot I$ \\
\hline \multicolumn{7}{|l|}{ Non-essential: } \\
\hline Glutamic & 12.9 & $13 \cdot 9$ & $12 \cdot 5$ & 15.0 & $14 \%$ & 15.0 \\
\hline Alanine & 8.9 & 6.6 & $7 \cdot 8$ & $8 \cdot 8$ & $7 \cdot 2$ & $10 \cdot 0$ \\
\hline Aspartic & $8 \cdot 8$ & $12 \cdot 7$ & 14.0 & II $\cdot 4$ & $9 \cdot I$ & 10.5 \\
\hline Glycine & $7 \cdot 5$ & $8 \cdot 4$ & $8 \cdot 8$ & $7 \cdot 2$ & 10.6 & $2 \cdot I$ \\
\hline Serine & $5 \cdot 5$ & $5 \cdot 2$ & $7 \cdot 8$ & $5^{\circ} 9$ & $7 \cdot 1$ & $3 \cdot 0$ \\
\hline Proline & 4.7 & $5 \cdot 2$ & $5 \cdot 5$ & $7 \cdot 5$ & $5 \cdot 7$ & $7 \cdot 2$ \\
\hline Arginine & $4 \cdot 5$ & $6 \cdot 5$ & $5 \cdot 1$ & $9 \cdot 8$ & $7 \cdot 9$ & $5^{\circ} 0$ \\
\hline Tyrosine & 3.0 & $2 \cdot 9$ & 3.9 & $\mathrm{I} \cdot 4$ & $3 \cdot 6$ & $2 \cdot 5$ \\
\hline
\end{tabular}

Table 4. Molar percentage proportions of free amino acids in different staple foodstuffs in East Africa

\begin{tabular}{|c|c|c|c|c|}
\hline Amino acid & Plantain & $\begin{array}{l}\text { Sweet } \\
\text { potato }\end{array}$ & $\begin{array}{l}\text { Ground- } \\
\text { nuts }\end{array}$ & Cassava \\
\hline \multicolumn{5}{|l|}{ Essential: } \\
\hline Leucine & 3.14 & $4 \cdot 5$ & 0.72 & 0.29 \\
\hline Lysine & 160 & 0.78 & 0.22 & $3 \cdot 87$ \\
\hline Valine & $\mathrm{I} \cdot 4 \mathrm{I}$ & 7.9 & $7 \cdot 00$ & 0.88 \\
\hline Threonine & $16 \cdot 5$ & $9 \cdot 7$ & $2 \cdot 53$ & 3.23 \\
\hline Isoleucine & I.10 & 3.8 & $x \cdot 68$ & 0.19 \\
\hline Phenylalanine & 3.92 & $4 \cdot 5$ & $9 \cdot 9$ & $12 \cdot 5$ \\
\hline Methionine & 0.16 & $2 \cdot \mathrm{I}$ & - & 二 \\
\hline Histidine & $28 \cdot 2$ & 17 & 0.82 & $3 \cdot 08$ \\
\hline \multicolumn{5}{|l|}{ Non-essential: } \\
\hline Glutamic & 5.49 & $18 \cdot 0$ & $46 \cdot 3$ & $11 \cdot 7$ \\
\hline Alanine & 4.24 & $7 \cdot 7$ & $8 \cdot 44$ & $I I \cdot r$ \\
\hline Aspartic & $9 \cdot 42$ & $18 \cdot 2$ & $7 \cdot 45$ & $10 \cdot 6$ \\
\hline Glycine & $1 \cdot 4 \mathrm{I}$ & $2 \cdot 8$ & $3 \cdot 6 \mathrm{I}$ & $\mathrm{I} \cdot 66$ \\
\hline Serine & $6 \cdot 27$ & $9 \cdot 8$ & $3 \cdot 38$ & $5 \cdot 87$ \\
\hline Proline & $4 \cdot 39$ & $5 \cdot 2$ & 4.70 & $24 \cdot 4$ \\
\hline Arginine & $6 \cdot 27$ & 0.89 & 1.40 & $9 \cdot 35$ \\
\hline Tyrosine & I.10 & $2 \cdot 9$ & $1 \cdot 01$ & 0.29 \\
\hline Total ( $\mu$ moles $/ g$ wet $w t)$ & $13 \cdot 0$ & $9 \cdot 0$ & $8 \cdot 0$ & $5 \cdot 0$ \\
\hline
\end{tabular}


The histidine content was high in the free amino acids (Table 4 ) as well as the protein (Table 3 ). In the cassava the high arginine and proline of the protein was again reflected in the composition of the free amino acids.

Table 5. Estimated tryptophan content of a variety of foods

\begin{tabular}{|c|c|c|}
\hline Material tested & $\begin{array}{l}\text { Tryptophan } \\
\text { content } \\
\text { (mg/roo } g \\
\text { food) }\end{array}$ & $\begin{array}{c}\text { No. of } \\
\text { samples } \\
\text { tested }\end{array}$ \\
\hline Dried skim milk & 500 & - \\
\hline Bovine albumin & 500 & - \\
\hline Casein & 1500 & $一$ \\
\hline Groundnuts & $\begin{array}{l}315 \\
335 \\
337\end{array}$ & $\begin{array}{l}2 \\
6 \\
4\end{array}$ \\
\hline Stock laboratory diet $(\mathrm{SG} \mathbf{I})^{*}$ & $\begin{array}{l}265 \\
335\end{array}$ & $\begin{array}{r}4 \\
12\end{array}$ \\
\hline Hay & $\begin{array}{l}55 \\
65 \\
82 \cdot 5\end{array}$ & $\begin{array}{l}2 \\
2 \\
2\end{array}$ \\
\hline Carrots & ND & 一 \\
\hline Cassava & ND & - \\
\hline Potato & $\begin{array}{l}22 \\
30\end{array}$ & $\begin{array}{l}2 \\
4\end{array}$ \\
\hline Sweet potato & ND & - \\
\hline Banana & ND & - \\
\hline Cabbage & $\begin{array}{l}\text { I } 5 \\
25\end{array}$ & $\begin{array}{l}2 \\
4\end{array}$ \\
\hline
\end{tabular}

\section{Amino acid composition of meat}

The amino acid composition of skeletal muscle protein was previously determined (after washing out free amino acids and peptides) for eight mammalian species (Crawford, Patterson \& Yardley, I968). We have now extended this analysis to fifteen different species including man (Crawford et al. 1968). These were plotted in order of their quantitative significance (Fig. 2). Micromolar quantities were used in order to establish the relative quantitative importance. Milligramme quantities might confuse the picture as different amino acids have different molecular weights. From the small standard deviation for each amino acid it seemed that, regardless of species, the proportionate amino acid composition of muscle was similar. The main analysis was done on skeletal muscle samples because these were readily available. Results for samples of heart muscle from man, monkey and ox suggest that heart has a pattern similar to that found for skeletal muscle.

The close agreement of amino acid composition regardless of species and hence diet, suggests that this profile may be of importance in relation to quantitative requirements and the ideal balance of amino acids for construction of muscle protein (Crawford et al. I968). 


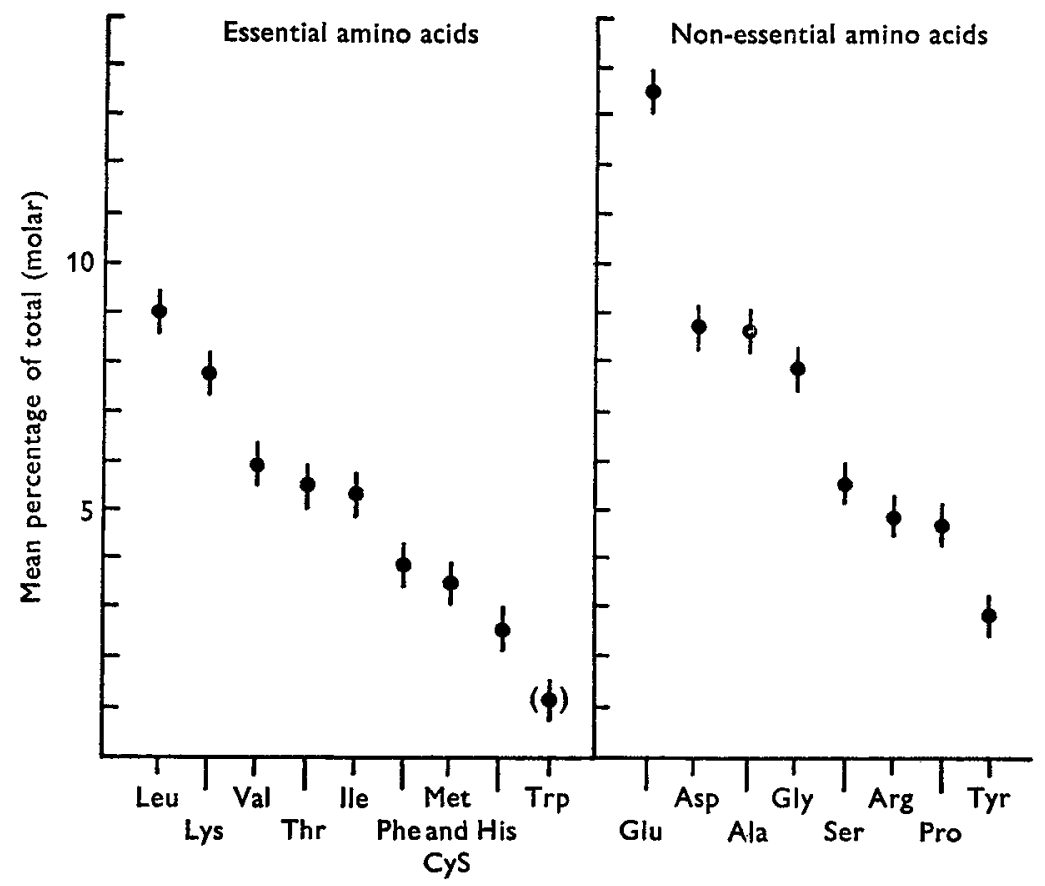

Fig. 2. Order of quantitative importance of amino acids from mammalian muscle protein, plotted as the mean and \pm twice the standard deviation. Fifteen species were used in this investigation: domestic ox, pig, sheep, man, patas monkey, elephant, warthog, kob, topi, hartebeest, eland, buffalo, giraffe, leopard and hyena. The point shown in parentheses was estimated by a different method.

\section{DISCUSSION}

We are interested in the question of nutrition and the tropical cardiomyopathies, particularly endomyocardial fibrosis. For a study on plasma amino acids in adults to be relevant to heart muscle it should be related to muscle amino acid composition, an important determinant of demand. We reported that the amino acid composition of muscle tissue from eight herbivores was similar regardless of species or diet (Crawford et al. 1968). We have extended and confirmed this finding to omnivores and carnivores, and included man (Fig. 2).

Consequently, it was interesting that the plasma amino acids of Africans at risk to endomyocardial fibrosis were low in leucine, one of the amino acids quantitatively most important in the muscle protein profile. Of the other essential amino acids, tryptophan was significantly lower in the plasma of Africans at risk to endomyocardial fibrosis, but Africans (mostly Luo) using grains with some fish and some milk foods had intermediate values compared with Europeans and others thought not to be at risk (Table 2). Valine also appeared to be lower in the plantain-root crop group considered to be at risk to endomyocardial fibrosis.

Whilst leucine is quantitatively one of the most important essential amino acids for protein construction, tryptophan is the least important (Fig. 2). Tryptophan is used for the construction of the oxidative co-enzymes which are important to tissues such 
as the heart and adrenals with high oxygen consumptions. Protein synthesis is also particularly sensitive to tryptophan deficiency (Pronczuk, Baliga, Triant \& Munro, rg68).

In protein-calorie malnutrition in children, or in kwashiorkor, there is a change in the plasma amino acid pattern (Hansen \& Brock, 1964; Brock, Hansen, Howe, Davel, Pretorius \& Hendrickse, 1955; Dean \& Whitehead, 1964), and Whitehead (1964, 1965) has used the change in the ratio of essential to non-essential amino acids as a test of clinical and subclinical protein malnutrition.

The essential amino acids most affected in plasma have been found to be leucine and valine. Tryptophan is sometimes not estimated because of the difficulties involved. It is interesting that we have now shown that a similar state appears in adults (Table I). Although the changes in essential and non-essential amino acids were not as gross in our adults as might be expected in malnourished children, the importance of amino acids for which muscle tissue has a high demand should be emphasized. If tryptophan is present at $\mathrm{I} \%$ of the total, then from our analysis (Fig. I) every molecule of tryptophan is accompanied by nine of leucine and if other amino acids are present in adequate supply, then protein synthesis can proceed. If the tryptophan molecule is accompanied by eight molecules of leucine synthesis will be limited. Hence the availability of the amino acids present in relatively large amounts may be as critical or more critical than those present in small amounts.

Analysis of the food materials used as staples (Tables 3-5) by the African communities indicated that, apart from the low protein content, the protein itself is imbalanced by comparison with the muscle profile. For example, the histidine proportion in plantain and the arginine in cassava are high. Holton (1968) has shown in experiments on histidine loading that a high histidine intake alters the balance of amino acids in the plasma. The effect included a reduction of the levels of valine, isoleucine and leucine and an increase in threonine and some of the non-essential amino acids. We have shown (Gale \& Crawford, r969) that histidine fed to guinea-pigs on a normal diet encourages weight gain; when fed to guinea-pigs on low-protein diets, at levels similar to those found in the plantain, there was an impairment of growth. The same was found in parallel experiments using arginine at levels similar to the cassava pattern. It is known that the incorrect balance of amino acids leads to competition for utilization (Harper, r962, 1967; Christensen, r963; Harper, Becker \& Stucki, 1966; Harper, Leung, Yoshida \& Rogers, I964; Milne, I968).

The incidence of tropical cardiomyopathies is reported to be highest in the lowest socio-economic groups (Shaper \& Coles, 1965); these people live on low-protein, lowfat, high-carbohydrate diets. We have now seen that changes in plasma amino acids can be detected in response to these diets which, although not so gross, are similar to those seen in protein malnutrition in children. Because the nature of these changes is relevant to a consideration of muscle construction, the question is naturally raised as to their relationship to the degenerative muscle disorders seen in the tropical cardiomyopathies. It is possible that chronic nutritional imbalance may be related to cardiomyopathies either in the sense of a direct intolerance of the imbalance or a chronic insufficiency for maintenance and repair (Crawford, $1968 c$ ). 
This study was generously supported by grants nos. R. 1568 and R $1780 \mathrm{~A}$ of the Ministry of Overseas Development. We are also grateful to the British Empire Cancer Campaign, the East African Medical Research Council, Makerere University College Grants Committee and H. J. Heinz and Company for financial assistance. Professor $\mathrm{K}$. Somers is indebted to the British Heart Foundation for financial support.

\section{REFERENCES}

Banwell, J. \& Crawford, M. A. (1963). Biochem. F. 89, 69 P.

Bennett, F. J., Jelliffe, D. B., Jelliffe, E. F. P. \& Moffat, M. (г968). E. Afr. med. J. 45, 229.

Brock, J. F., Hansen, J. D. L., Howe, E. E., Davel, J. G. A., Pretorius, P. J. \& Hendrickse, R. G. (I955). Lancet ii, 355 .

Busson, F. (1965). Plantes alimentaires de l'ouest africain. Marseilles: Leconte.

Christensen, H. N. (1963). Fedn Proc. Fedn Am. Socs exp. Biol. 22, I 110.

Crawford, M. A. (1964). E. Afr. med. 7. 4r, 228.

Crawford, M. A. (1968a). Adv. Pharmac. 6, I76.

Crawford, M. A. (1968b). Vet. Rec. 82, 305.

Crawford, M. A. (1968c). Proc. Nutr. Soc. 27, 163.

Crawford, M. A., Patterson, J. \& Yardley, L. (1968). Symp. zool. Soc. Lond. no. 21, p. 367.

Dean, R. F. A. \& Burgess, H. J. L. (r962). E. Afr. med. F. 39, 356.

Dean, R. F. A. \& Whitehead, R. G. (1964). Lancet ii, 98.

Denckla, W. D. \& Dewey, H. K. (I967). F. Lab. clin. Med. 69, 160.

Gale, M. M. \& Crawford, M. A. (1969). Trans. R. Soc. trop. med. Hyg. 63, 821, 826.

Greaves, J. P. \& Tan, J. (I966). Nutrition 20, I12.

Gustafsson, B. E. (1968a). Ciba Fdn Study Grps no. 31, p. 3.

Gustafsson, B. E. (1968b). Ciba Fdn Study Grps no. 31, p. 66.

Hansen, J. D. L. \& Brock, J. F. (1964). Lancet i, 1278.

Hansen, I. L. \& Crawford, M. A. (I966). F. Chromat. 22, 330.

Harper, A. E. (1962). Am. F. clin. Nutr. Ir, 382.

Harper, A. E. (1967). In The Chemical Senses and Nutrition, p. I55. [Morley R. Kare and Owen Maker, editors.] Baltimore, Maryland: The Johns Hopkins Press.

Harper, A. E., Becker, R. V. \& Stucki, W. P. (I 966). Proc. Soc. exp. Biol. Med. 121, 695.

Harper, A. E., Leung, P., Yoshida, A. \& Rogers, Q. R. (1964). Fedn Proc. Fedn Am. Socs exp. Biol. 23, 1087 .

Holton, J. B. (1968). Clin. chim. acta 21, 241.

Lombard, J. H. \& de Lange, D. J. (1965). Analyt. Biochem. ro, 260.

Milne, M. D. (1968). Clin. Pharmac. Ther. 9, 484.

Milne, M. D., Crawford, M. A., Girao, C. B. \& Loughridge, L. (I960a). Q. $\mathscr{l}$ Med. 29, 407.

Milne, M. D., Crawford, M. A., Girao, C. B. \& Loughridge, L. (1960b). Clin. Sci. 19, 165.

Pronczuk, A. W., Baliga, B. S., Triant, J. W. \& Munro, H. N. (1968). Biochim. biophys. Acta r57, 204.

Shaper, A. G. \& Coles, R. M. (1965). Br. Heart F. 27, 121.

Somers, K., Brenton, D. P. \& Sood, N. K. (1968). Br. Heart F. 30, 309.

Somers, K. \& D'Arbela, P. G. (r964). International Topic on the Epidemiology of Cardiovascular Diseases: Heart Disease in Uganda. Proceedings of the Third Asian-Pacific Congress of Cardiology, Kyoto. Vol. 1, p. 162 .

Tulloch, J. A., Kanyerezi, R. B., D'Arbela, P. G. \& Sood, N. K. (1968). Trans. R. Soc. trop. med. Hyg. 62, 362 .

Uganda Atlas (1962). Lands and Surveys Department, Uganda Government.

Weissbach, H., King, W., Sjoerdsma, A. \& Udenfriend, S. (1959). F. biol. Chem. 234, 81.

Whitehead, R. G. (1964). Lancet i, 250.

Whitehead, R. G. (1965). Lancet ii, 567. 